well-understood custom, called to vaccinate the child. I was not a little astonished when the mother expressed her regret at the trouble I was put to, informing me, at the same time, that the child was already vaccinated. She then went on to explain that one day, a short time previously, a medical gentleman, perfectly strange to her, called, and all but insisted upon his vaccinating the child, informing her she would otherwise be liable to be severely fined, he being appointed to vaccinate all for that district. She objected to this, informing him she expected her " family doctor" calling daily to do it, as he had done the other. But eventually, owing to the absence of her husband, and the dread of the fine for non-compliance, she reluctantly assented. The child was vaccinated, and medicine sent and paid for. The husband expresses himself as very dissatisfied and angry with such interference, and taking advantage of his absence to alarm his wife into compliance.

I submit to the profession the propriety of a parish vaccinator going into the houses of respectable tradesmen, who are both able and willing to pay their own medical attendant, unsought and objected to, but accomplishing his purpose by the anything-butprofessional means above detailed.

So long as such vaccinator confined his operations to the "back-slums and by-ways," hunting up and vaccinating the needy poor, for which purpose, in my humble opinion, his office was created, he would be acting meritoriously, and but fulfilling his proper duty.

\section{PREPARATIONS OF IRON.}

To the Editor of THE LANCET.

SIR, - I beg to forward you the following formulæ for the use of the general practitioner, being at once eligible and economical, requiring but little trouble in the preparation, and always to be depended upon, as to the proportion of the active ingredient in a given quantity of the liquid. I am, Sir, your very obedient servant,

$$
\text { JoH N ToDp, M.D., }
$$

King's College, Aberdeen.

Mare-street, Hackney, Sept. 5, 1842.

LYQUOR FERRI POTASSIO-CITRATIS.

R Acid. citric. crystallizat., 3 j. $3 \mathrm{v}$;

Potassa carbonatis, $3 \mathrm{vij}$;

Ferri sesquioxyai, $\widetilde{z} j$;

Sp. ammonia aromat., q. s.;

Aqua distillat., $\overline{3} \times x i v$.

Dissolve the acid. citric. and potass, carbonat. in the water, when the effervescence has ceased, add the ferri sesquioxyd., and digest for twenty-four hours (frequently stirring) in a gentle heat; filter the fiquid, and neutralise any excess of acid by dropping in, gradually, sp. ammon. arom., until it is saturated. The liquid is of a reddish-brown colour, not precipitated by alkalies, nor altered in colour by the ferrocyanide of potassium, or tincture of galls. The taste is slightly styptic, though not unpleasant. It will be seen that there are two equivalents of acid. citric. combined with one equivalent of potass. and one equivalent of the ferri sesquioxyd. :-one drachm of this solution contains five grains of the dry ferri potassio-citras.

An agreeable syrup may be made by dissolving sacchar. alb., $l b . j$ in $f \xi$ viij of the solution, and liquefying by a gentle heat. We have thus $f \bar{z} x$ viij of syrup; consequently $f 3 j$ will contain 2.25 grains.

\section{SYRUPUS FERRI IODIDI.}

\section{R Todine, grs. 362 ;}

Ferri limatur., grs. 90;

Aque distillat., 亏ैiij ;

Sacchar. alb., lb.j.

Digest the iodine and iron in the water until it become nearly colourless; pour off the clear liquid, and dissolve the sacchar. alb. with a gentle heat. When cold, pour off the clear syrup, and keep it in half-pint bottles well corked, and in the dark. The deoxydising agency of the sugar renders it unnecessary to keep a piece of iron wire in the bottle. As no precipitate takes place, except when exposed to a strong light, and air combined. In this, 362 grains of iodine combined with 80 grains of iron, forming 442 grains of ferri iodidi, dissolved in water $\xi$ viij, which by the solution of the sacchar. alb., lb. $j$ makes $3 \times v i i j$, being three grains of ferri iodidi in $f 3 j$ of the syrup.

\section{QUESTION OF WINDOW-TAX ON HOSPITALS.}

\section{THE FEVER HOSPITAL.}

The 48 Geo. 3, c. 55, imposes a duty on dwelling-houses for not more than six windows or lights, and for seven windows or lights, and exempts hospitals, except officers" and servants' apartments, which it declares should be assessed as entire dwelling-houses; the $6 \mathrm{Geo} .4$, c. 7 , s. 1, repeals the above duties. Held, that the duty on dwellinghouses, for not more than six and for seven windows being so taken away, it must be likewise deemed to be taken off the officers' and servants' apartments in hospitals, such apartments being, by the clause of the repealed Act, so treated and assessed as dwelling-houses.

\section{Middlesex, Holborn Division.}

At a meeting of the commissioners of assessed taxes, acting for the said division, holden at the board-room, No. 24, Red Lionsquare, in the said division, the 3rd day of September, 1841, Mr. Hyde appealed 
against an assessment made on him as secre- $f$ in the said division, as follows:-C (48. Geo. 3 , tary to the Fever Hospital, at Battle-bridge, c. 55, sch. (A), rule 8.)

Exemptiong-Case 2.

\begin{tabular}{|c|c|c|c|}
\hline $\begin{array}{l}\text { Name of Inhabitant. } \\
\text { Charles Hyde, secretary to the } \\
\text { Fever Hospital, Battle-bridge. }\end{array}$ & $\begin{array}{c}\text { Description. } \\
\text { Matron's apartments } \\
\text { and } \\
\text { Honsemaids....... } \\
\text { Medical officers..... } \\
\text { 10l. per cent....... }\end{array}$ & $\begin{array}{l}\text { Windows. } \\
\text { No. } \\
\quad 4\end{array}$ & $\begin{array}{cc}\text { Duty. } \\
\text { s. } \\
7 & 0 \\
& 0 \\
7 & 0 \\
1 & 4 \\
\end{array}$ \\
\hline
\end{tabular}

The commissioners relieved the premises from charge, under case 2 , exemptions, 48 Geo. 3, c. 55, schedule (A); but the surveyor being dissatisfied with such determination, requested us to state a case for the opinion of her Majesty's judges, which we state accordingly.

The 48 Geo. 3, c. 55, imposes duty on every dwelling-house according to the number of windows or lights in each dwellinghouse, and the offices to be charged therewith, viz. :-

Schedule (A.) - Not more than six windows or lights, except in such house which shall be worth the rent of $5 l$. by the year, and shall be charged to the duty mentioned in schedule (B), according to the rent more than six windows or lights, if of the value before-mentioned, and charged to the said duty accordingly............

Seven windows or lights ........ 10

Eight windows $\ldots \ldots \ldots \ldots \ldots \ldots, 13$ And so on.

By case 2 of exemption from window duty, any hospital, charity-school, or house provided for the reception and relief of poor persons, except such apurtments therein as are or may be occupied by the officers or servants thereof, which shall severally be assessed and be subject to the said duties as entire dwellinghouses.

By the 6 Greo. 4 , c. 7 , s. 1 , the duties imposed by 48 Geo. 3, as set forth in the schedule thereto annexed, marked (A), for every dwelling-house, with the offices therein described, containing not more than six windows or lights, \&c., and for every dwellinghouse containing not more than seven windows or lighis, are repealed.

The Fever Hospital is a hospital provided for the reception and relief of poor persons, and supported by voluntary contributions.

The commissioners are of opinion, that previousiy to the passing of 6 Geo. 4, the apartments in question (containing only four windows each), would have been severally assessable as entire drelling-houses, with the duty imposed by the said first-mentioned Att, on entire dwelling-houses with not more than six windows, $6 \mathrm{~s}$. $6 \mathrm{~d}$. or $8 \mathrm{~s}$., as the case might be, according to the rental of the premises in question (under schedule $(B)$ of the said Act, which said schedule (B) was repealed by the 4 Will. 4 , c. 19); but inasmuch as the Act im posing the window duty (48 Geo. 3, c. 55, is repealed, quoad the duties on houses with less than seven windows, it follows that since the passing of 6 Geo. 4, c. 7, there exists no rule for charging the apartments in question, seeing that no rule existed for charging them except as entire $d w e l l i n g-h o u s e s$, and they therefore fall wholly within the exemption, case 2, before set forth. The exception to such exemption, operating under 48 Geo. 3 , us a rule for charging, viz., as entire dwellinghouses, but which rule for charging is repealed by 6 Geo. 4 , thus leaving the exemption entire as to hospitals, \&c., provided for the reception and relief of poor persons, where the apartments occupied by the officers do not contain more than seven windows.

The surveyor, however, has charged the apartments in question, under rule 8 of 48 Geo. 3, c. 55, for charging windows or lights, viz. :-

"Every distinct chamber ar apartment in any of the inns of court or of chancery, or in any college or hall, or in either of the Universities of Oxford or Cambridge, or any public hospital, being severally in the tenure or occupation of any person or persons, shall be subject to the same duties as if the same was an entire house, which duties shall be paid by the occupier thereof respectively; provided that every such chamber or apartment which shall not contain more than seven windows or lights, shall be charged at the rate of three shillings and sixpence for every such window or light," reduced by the 4 (1)eo. 4, c. 11, to one moiety.

The commissioners are of opinion, that this rule does not apply to a hospital for the reception and relief of poor persons; but to public hospitals, such as Greenwich and Chelsea fiospitals, the separate apartments in one of these latter establishments, having not mure than seven windows, are still chargeable with a duty of 1s. 9d., one moiety of 3s. 6a. for each window, because this rule for charging public hospitals is not 


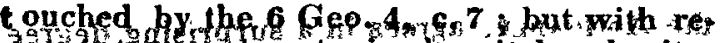
spect to apartments in hospitals, charity-

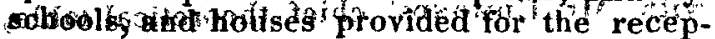
fion ; and relief of poror pertorn's, there does not exist, so far as the commissionerg can afscover, atty rule for charging them.

"The surveyor, in support of his charge, contends that the 8 thr rule of $48 \mathrm{Geo} 3, \mathrm{c}$. $5 \mathbf{5}$, is not affected by the exemption granted by the first section of the Act, 6 Geo. 4, c. 7, inasinacli as no reference is made therein to chambers or apartments mentioned in the said rule, but only to dwelling-houses, containing " pot more than seven windows or lights," and which in his opinion was intended to give relief to poorer classes as occupiers thereof, and not to hospitals, charity-schools, or houses provided for the reception and relief of poor persons, the apartments occupied by the officers or servants thereof being expressly excepted in the second case of exemptions in the Act, 48 Geo. 3, c. 55, and the surveyor refers to the printed case, No. 1154, decided by the judges in respect to the liability of the officers of the Westminster Hospital, at the rate of 1.s. 9d. for each window in their several apartments, and which decision was given subsequent to the passing of the Act 6 Geo.4, c. 7 .

, The commissioners beg to observe, that in the case, No. 1154, referred to by the surveyor, the attention of the judges was not called to the distinction between rule 8 , for charging public hospitals, and case 2 of exemptions, or rule for charging hospitals provided for the reception of poor persons; nor was their attention called to the 6 Geo. 4 , repealing the duties on dwelling-houses containing not more than seven windows.

Given under our hands this 7 th day of January, 1842.

$$
\begin{aligned}
& \text { James Mansfield, } \\
& \text { John Till, } \\
& \text { EDWard Baylis, }
\end{aligned}
$$

29 !h June, 1842.-We are of opinion that the determination of the commissioners is right.

J. Patteson, J. WILLIAMS.

From the Justice of the Peace, Aug. 1842.

Death from Thomsonism. - Dr. John Butterfield; of Lowell, Mass., reports, in the Boston Journal for May 11 th, a case of erysipelas, " in the onset not severe," in which the patient was treated by a Thomsonian quack. He took capsicum, was put through a regular course, and finally steamed three times in twenty-four hours! In a state of coma with convulsions, be was hauded over to the "regulars," and died after lingering a sbort time.-Philadelphia Med. Examiner.

\section{sitit}

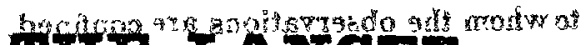

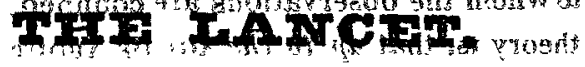

-

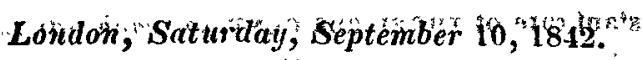

WE have this week received,-but notin sufficient time to publish it until the issue of the next number of THE LANGET, - an artiele of very remarkable excellence and interest; from the pen of Mr. Ebnonas; Actuary-of the Legal and General Assurance Opfice; im Fleet-street, the history and an outline of which we shall give in this place. Itso origin takes date from the publication about six months ago, of a statement by the Amicable Assurance Society, of the mortari lity experienced by the members of : that so: ciety during the thirty-three years precedings the 5th of April, 1841. Mr. Emmonds lad made an investigation of the facts therein given; and wished to compare the results with the're: sults of his previous observation on the mot tality of the members of the EaUITA BLF As-: SURANCE Socrety which appeared in ThE: LANCET of October 28, 1837, page 15.4, But he found that the comparison could not be readily and directly instituted, in conse:-" quence of the classifications which he had made of the facts in the two observations being, in some degree, different. Hews hence lid to desire to institute, and afterwards: undertake, an entirely new investigation of the facts reported by the Eavitable. The results of his labour are embodied in the form of a complete analysis of all the information that was capable of being extracted from the two observations on the members of the Amicable and Equitable Societies, his present classim? fication of the facts being of a more general, and, as Mr. EDmonds considers, a more usefud character than that which was prexiously b adopted by him, in the case of the EQuTTA $B L E$, in the year 1837.

In noticing the fruits of these-two ob-ifs servations we may here mention that the -4 sults arrived at fiom both observations are

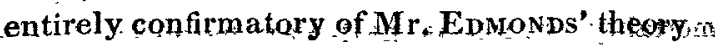
of human mortality, at least among adultsyz 